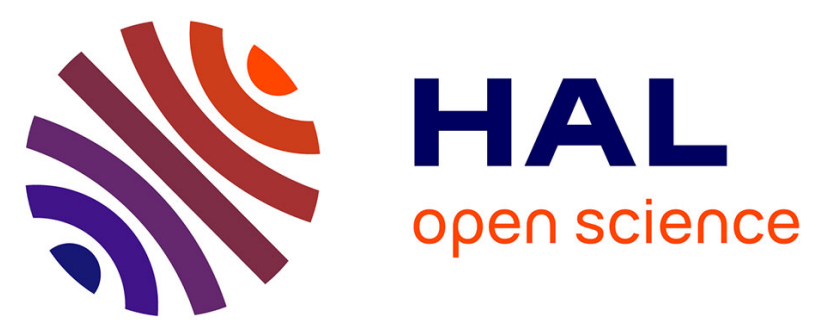

\title{
Reasons for non-intensification of treatment in people with type 2 diabetes receiving oral monotherapy: Outcomes from the prospective DIAttitude study
}

Beverley Balkau, Serge Halimi, Jean-Frédéric Blickle, Bruno Vergès, Antoine Avignon, Claude Attali, Isabelle Chartier, Elisabeth Amelineau

\section{To cite this version:}

Beverley Balkau, Serge Halimi, Jean-Frédéric Blickle, Bruno Vergès, Antoine Avignon, et al.. Reasons for non-intensification of treatment in people with type 2 diabetes receiving oral monotherapy: Outcomes from the prospective DIAttitude study. Annales d'Endocrinologie, 2016, 77 (6), pp.649-657. 10.1016/j.ando.2016.03.001 . hal-01819501v2

\section{HAL Id: hal-01819501 \\ https://hal.umontpellier.fr/hal-01819501v2}

Submitted on 5 Dec 2019

HAL is a multi-disciplinary open access archive for the deposit and dissemination of scientific research documents, whether they are published or not. The documents may come from teaching and research institutions in France or abroad, or from public or private research centers.
L'archive ouverte pluridisciplinaire HAL, est destinée au dépôt et à la diffusion de documents scientifiques de niveau recherche, publiés ou non, émanant des établissements d'enseignement et de recherche français ou étrangers, des laboratoires publics ou privés. 


\title{
Reasons for non-intensification of treatment in people with type 2 diabetes receiving oral monotherapy: Outcomes from the prospective DIAttitude study
}

\author{
Raisons de la non-intensification du traitement du diabète de type 2 sous traitement oral en \\ monothérapie : résultats de l'étude prospective DIAttitude
}

\author{
Beverley Balkau $^{\mathrm{a}, *}$, Serge Halimi ${ }^{\mathrm{b}}$, Jean-Frédéric Blickle ${ }^{\mathrm{c}}$, Bruno Vergès ${ }^{\mathrm{d}}$, Antoine Avignon ${ }^{\mathrm{e}}$, \\ Claude Attali ${ }^{\mathrm{f}}$, Isabelle Chartier ${ }^{\mathrm{g}}$, Elisabeth Amelineau ${ }^{\mathrm{h}}$ \\ a Inserm U-1018, CESP, Team 5 (EpReC, Renal and Cardiovascular Epidemiology), UVSQ-UPS, 94807 Villejuif, France \\ ${ }^{\mathrm{b}}$ Université Grenoble Alpes (UJF), 38043 Grenoble, France \\ ${ }^{\mathrm{c}}$ Hôpitaux Universitaires, 67000 Strasbourg, France \\ ${ }^{\mathrm{d}}$ CHU de Dijon, 21079 Dijon, France \\ e CHU de Montpellier, 34000 Montpellier, France \\ ${ }^{\mathrm{f}}$ Université Paris Est, Faculté de Médecine, 94010 Créteil, France \\ ${ }^{\mathrm{g}}$ Aixial-Pharma, 92300 Levallois-Perret, France \\ ${ }^{\mathrm{h}}$ Bristol-Myers Squibb, 92500 Rueil-Malmaison, France
}

\begin{abstract}
Objectives. - To describe the management of glucose-lowering agents in people with type 2 diabetes initially on oral monotherapy, cared for by French general practitioners, and to identify reasons underlying treatment non-intensification. Methods. - People with type 2 diabetes on oral monotherapy were recruited by general practitioners and followed-up over 12 months. Patient characteristics, HbA1c, and glucose-lowering treatments were recorded electronically. Management objectives and reasons for treatment non-intensification were solicited from the general practitioners. Results. - A total of 1212 patients were enrolled by 198 general practitioners; 937 patients (mean age 68 years) were treated with oral monotherapy, and 916 patients had at least two successive HbAlc values recorded. Of these, 390 patients (43\%) had HbAlc $\geq 6.5 \%$ on both occasions, and 164/390 (42\%) had their treatment intensified. The 226 patients whose treatment was not intensified were older ( $69 \pm 11$ years vs. $66 \pm 12$ years, $P=0.02)$ and had better glycaemic control at study inclusion $(6.9 \% \pm 0.6$ vs. $7.3 \% \pm 0.8, P<0.0001)$ than treatment intensified patients. Among uncontrolled patients, there were no differences in general practitioner treatment objectives at inclusion for treatment intensified and non-intensified patients; the main reason given by general practitioners for non-intensification was that the patient had an adequate HbA1c (66\%). HbA1c did exceed the $6.5 \%$ target, but was less than $7.0 \%$ in $69 \%$ of cases. Conclusions. - General practitioners showed a patient-centred approach to treatment, but clinical inertia was apparent for $31 \%$ of the uncontrolled patients.
\end{abstract}

Keywords: Clinical inertia; HbA1c; Oral glucose-lowering medication; Pharmacoepidemiology; Treatment intensification; Type 2 diabetes

\section{Résumé}

Objectifs. - Décrire les pratiques des médecins généralistes français concernant l'intensification du traitement des diabétiques de type 2 maléquilibrés et traités au départ par hypoglycémiants oraux en monothérapie et identifier les raisons d'une non-intensification du traitement. Méthodes. - Des diabétiques de type 2 sous monothérapie orale ont été recrutés par des médecins généralistes et suivis pendant 12 mois; leurs caractéristiques, HbAlc et traitements hypoglycémiants ont été enregistrés par électronique. Les objectifs de prise en charge par les médecins généralistes et les raisons d'une non-intensification de traitement ont été notés. Résultats. - Un total de 1212 patients avec un diabète de type 2 ont été recrutés par 198 généralistes ; 937 (âge moyen 68 ans) ont été traités par hypoglycémiant oral en monothérapie, parmi lesquels 916 ont eu au moins deux 
mesures successives d'HbA1c. Parmi eux, 390 (43\%) ont présenté une HbA1c $\geq 6,5 \%$ deux fois au cours du suivi, et 164/390 (42\%) ont bénéficié d'une intensification de traitement. Les 226 patients n'ayant pas bénéficié de cette intensification étaient plus âgés ( $69 \pm 11$ vs $66 \pm 12$ ans, $p=0,02)$ et présentaient une meilleur équilibre glycémique à l'inclusion $(6,9 \% \pm 0,6$ vs $7,3 \% \pm 0,8, p<0,0001)$. Parmi les patients non-équilibrés, il n'y avait pas de différence des objectifs de traitement à l'inclusion selon qu'ils aient bénéficié d'un traitement intensifié ou pas ; les raisons d'une non-intensification étaient que l'HbA1c (66\%) étaient adéquates. En effet, l'HbA1c dépassaient la valeur cible de 6,5\% de moins de 0,5\% dans $69 \%$ des cas.

Conclusions. - Les médecins généralistes ont montré une approche centrée sur leur patient. Pour $31 \%$ des patients mal-équilibrés, une inertie thérapeutique a toutefois été notée.

(C) 2016 Publié par Elsevier Masson SAS.

Mots clés : Diabète de type 2; HbA1c ; Inertie thérapeutique ; Intensification du traitement ; Médicaments hypoglycémiants oraux ; Pharmaco-épidémiologie

\section{Introduction}

The global burden of diabetes is a growing concern, and prevalence is projected to increase from 366 million in 2011 to 552 million by 2030 [1,2]. Long-term glycaemic control (reduction and maintenance of haemoglobin Alc $[\mathrm{HbAlc}]$ ) is an important clinical objective in the management of people with type 2 diabetes mellitus (T2DM) to reduce complications [3-5]. Glycaemic control is cost-effective [6], and better care should limit complications and the cost of healthcare. Most T2DM patients will progressively lose glycaemic control and require lifestyle advice and treatment intensification $[7,8]$.

Many physicians remain perplexed as to optimal treatment strategies for T2DM. In 2012, the American Diabetes Association (ADA) and the European Association for the Study of Diabetes (EASD) issued a joint position statement that specific patients may benefit from more stringent $\mathrm{HbAlc}$ objectives and more aggressive treatment (younger people with a shorter T2DM duration, no significant cardiovascular disease), and that conversely, less intensive treatment may be appropriate in elderly patients, and in those with long-term disease, a history of severe hypoglycaemia, or advanced complications and comorbidities [9]. At patient inclusion in the DIAttitude study, the 2006 French T2DM treatment guidelines were in use [10]; they recommended that, in cases where $\mathrm{HbA} 1 \mathrm{c}<6.5 \%$ was not achieved six months after treatment initiation, the first step was reinforcement of lifestyle advice, followed by the addition of one, two, then three oral glucose-lowering agents, and finally insulin (Table 1). In January 2013, T2DM treatment recommendations were updated by the French health authorities [11].

Many T2DM patients fail to maintain glycaemic control at target levels [12,13], and over half do not have their treatment intensified as recommended in the guidelines, which is a key reason for poor glycaemic control. This may be the result of 'clinical inertia', whereby physicians are reluctant to intensify therapy for fear of hypoglycaemia or weight gain, and fear of increasing patient anxiety [12-15]. It important to understand the barriers to treatment intensification and the reasons for nonadherence to treatment guidelines.

In France, cross-sectional studies report poor glucose control: in the 1999 ECODIA study, 1/3 of T2DM patients had an $\mathrm{HbA1c}>8 \%$ [16]; in the 2001 ENTRED study, the corresponding percentage was $25 \%$ [17], and this was lower at $15 \%$ in the
Table 1

Therapeutic recommendations for $\mathrm{T} 2 \mathrm{DM}$ in France (in use at the time the DIAttitude study was started) [11].

\begin{tabular}{|c|c|c|}
\hline Current $\mathrm{HbA} 1 \mathrm{c}$ & Treatment & HbA1c target \\
\hline $\begin{array}{l}\text { 6-6.5\% despite } \\
\text { lifestyle } \\
\text { recommendations }\end{array}$ & $\begin{array}{l}\text { Monotherapy with metformin (or } \\
\text { alpha-glucosidase inhibitor in } \\
\text { case of intolerance or } \\
\text { contraindication to metformin), } \\
\text { insulin secretor if } \\
\text { BMI }<27 \mathrm{~kg} / \mathrm{m}^{2}\end{array}$ & $<6.5 \%$ \\
\hline $\begin{array}{l}>6.5 \% \text { despite } \\
\quad \text { lifestyle } \\
\quad \text { recommendations }\end{array}$ & $\begin{array}{l}\text { Monotherapy with insulin } \\
\text { secretor, metformin, or } \\
\text { alpha-glucosidase inhibitor }\end{array}$ & Maintain $<6.5 \%$ \\
\hline $\begin{array}{l}>6.5 \% \text { despite } \\
\text { monotherapy and } \\
\text { lifestyle } \\
\text { recommendations }\end{array}$ & Dual oral therapy & $\begin{array}{l}\text { Reduce } \\
\text { to }<6.5 \%\end{array}$ \\
\hline $\begin{array}{l}>7 \% \text { despite dual } \\
\text { therapy and } \\
\text { lifestyle } \\
\text { recommendations }\end{array}$ & $\begin{array}{l}\text { Triple oral therapy or } \\
\text { insulin }+ \text { metformin } \pm \text { other oral } \\
\text { glucose-lowering treatments } \\
\text { except thiazolidinediones }\end{array}$ & Reduce to $<7 \%$ \\
\hline $\begin{array}{l}>8 \% \text { despite triple } \\
\text { therapy and } \\
\text { lifestyle } \\
\text { recommendations }\end{array}$ & $\begin{array}{l}\text { Insulin }+ \text { metformin } \pm \text { other oral } \\
\text { diabetic treatments except } \\
\text { thiazolidinediones }\end{array}$ & Reduce to $<7 \%$ \\
\hline
\end{tabular}

BMI: body mass index; HbAlc: glycosylated haemoglobin; T2DM: type 2 diabetes mellitus.

2007 ENTRED study [18-20]. The percentages with poor control suggest that therapeutic intensification, as recommended by the French Health Authorities [10,11], is not totally followed.

The DIAttitude non-interventional study aimed to describe therapeutic management of T2DM patients treated with oral glucose-lowering agents and cared for by French general practitioners (GPs), and to identify the main reasons for not intensifying treatment. Results from the 24-month retrospective phase have been reported $[21,22]$. The 12 -month prospective phase described in this report included T2DM patients treated with oral monotherapy.

\section{Methods}

\subsection{Study design}

French GPs in the Cegedim Strategic Data Longitudinal Patient Database (CSD-LPD) panel electronically record their 
activity and were invited to participate in the DIAttitude study. They uploaded anonymous excerpts from patients' medical files. This GP panel is validated by the French Health Authority as representative of practising French GPs.

Eligible patients were identified using a protocol-specific function in the patient database. Patient inclusion criteria were: age $\geq 18$ years; a recorded T2DM diagnosis; prescription of an oral glucose-lowering agent at the last visit; prescription of an oral glucose-lowering agent for at least six months; no insulin (or glucagon-like peptide [GLP]-1 receptor agonist) used during the past two years. GPs invited patients to participate in the study, and their characteristics and retrospective data from the previous 24 months were retrieved from electronic records (results previously reported $[21,22])$. The inclusion visit was the starting point for this 12-month prospective study, and only patients treated with oral monotherapy were included (Supplementary Fig. 1).

The study was conducted in accordance with the International Society for Pharmacoepidemiology Guidelines for Good Epidemiology Practices and applicable regulatory requirements. Data collection was approved by the French Commissions for data privacy (the Comité Consultatif sur le Traitement de l'Information en matière de Recherche sur la Santé and the Commission Nationale de l'Informatique et des Libertés).

\subsection{Data collected}

GP characteristics were recorded: age, gender, regional location, type of practice, member of a care network, specific training for diabetes, locally available specialists, total number of patients, and number of patients with T2DM seen in consultations per week. At inclusion, patient characteristics, (T2DM history, cardiovascular risk factors) and the GP's T2DM management objectives were recorded.

At three, six, nine and 12 months, the patient's physical examination, lifestyle, T2DM management, laboratory values and reasons underlying the GPS T2DM therapeutic decisions were recorded, as were glucose-lowering agent(s), treatment adjustment, treatment pattern (frequency and time between adjustments), HbA1c monitoring (frequency and timing), glycaemic control (frequency and duration of HbAlc exceeding defined targets), severe episodes of hypoglycaemia, weight, smoking, physical activity, blood pressure, and cholesterol levels.

\subsection{Definitions used}

A follow-up visit was defined as at least one questionnaire completed in a given three-month period. If a patient was seen several times in a three-month period, only the first visit occurring at least 75 days after the previous one was used.

Patients were taken to be 'uncontrolled' if they had two successive HbAlc values above the recommended target (HbA1c $\geq 6.5 \%$ for monotherapy) separated by at least 3 months and without treatment intensification between these two successive $\mathrm{HbAlc}$ values and for a 6 -month period before the first $\mathrm{HbA1c}$ value above the recommended target. Patients with a third $\mathrm{HbA} 1 \mathrm{c}$ below the recommended target after the second one were considered as 'controlled'. 'Uncontrolled' patients were considered to need treatment intensification. In addition, an $\mathrm{HbAlc}$ target of $\geq 7.0 \%$ was also analysed, as this is a commonly accepted glycaemic goal; the results for this glycaemic target are included in Supplementary tables.

A severe episode of hypoglycaemia was an episode requiring hospitalisation or assistance from another person.

\subsection{Statistical methods}

Patient characteristics are presented as mean \pm SD, median (quartile $1 \mid$ quartile 3), median (range), or $n(\%)$. Analyses compared intensified and non-intensified patients using Pearson $\mathrm{Chi}^{2}$, Fisher exact, Student $t$-test and Wilcoxon tests. Data were stratified according to patient age (75 years). Statistical significance was set at 5\%. Statistical analyses used SAS ${ }^{\circledR} 9.2$ (SAS institute, North Carolina, USA).

\section{Results}

\subsection{Participants}

Of the 1196 GPs participating in the CSD-LPD panel, 198 included at least one T2DM patient who was followed-up. GP age was $51 \pm 8$ years, and $82 \%$ were men. Active GPs were representative of practising GPs with respect to age, gender, and region of practice.

GPs enrolled 1212 patients in the prospective DIAttitude study: 971 were treated with oral glucose-lowering monotherapy, 937 had at least one follow-up visit, and 916 had at least two successive HbAlc measurements recorded (Supplementary Fig. 2). On average, patients had 3.2 clinic visits over the 12 months of follow-up, and 804 patients were followed-up for 12 months.

\subsection{Characteristics of the prospective study cohort at the index visit}

Of the 937 patients, $58.5 \%$ were men, with a mean age of 68 years, and 7.7 years duration of T2DM (Table 2). One third were aged 75 years or over, and $80.5 \%$ were overweight or obese.

Overall, $28.3 \%$ of patients had cardiovascular complications, and $25.5 \%$ had at least one microvascular complication (Table 2). The majority $(78.3 \%$ ) were treated for hypertension, and $44.3 \%$ were treated for dyslipidaemia.

Most patients were treated with metformin $(60.2 \%)$, followed by sulfonylureas (29.2\%) (Table 2). Patients under 75 years of age were more frequently treated with metformin than with sulfonylureas, whereas patients over 75 years had similar frequencies of these two treatments.

\subsection{Glycaemic control}

At inclusion, mean \pm SD and median (min-max) $\mathrm{HbA} 1 \mathrm{c}$ were $6.6 \pm 0.8 \%$ and $6.4 \%(4.8 \mid 11.5)$, respectively. While $51.6 \%$ had $\mathrm{HbA} 1 \mathrm{c}<6.5 \%$, below target, $24.1 \%$ had values between $6.5 \%$ 
Baseline characteristics of patients with type 2 diabetes included in the 12-month prospective phase of the DIAttitude study.

\begin{tabular}{|c|c|c|c|}
\hline & $\begin{array}{l}\text { Total } \\
n=937\end{array}$ & $\begin{array}{l}<75 \text { years } \\
n=632\end{array}$ & $\begin{array}{l}\geq 75 \text { years } \\
n=305\end{array}$ \\
\hline Men & $548(58.5)$ & $382(60.4)$ & $166(54.4)$ \\
\hline Age in 2010 (years) & $68 \pm 11$ & - & - \\
\hline$\leq 55$ years & $123(13.1)$ & - & - \\
\hline $55-65$ years & $246(26.3)$ & - & - \\
\hline $65-75$ years & $285(30.4)$ & - & - \\
\hline$>75$ years & $283(30.2)$ & - & - \\
\hline Time since T2DM diagnosis (years) & $7.7 \pm 6.6$ & $6.6 \pm 5.2$ & $10.2 \pm 8.4$ \\
\hline Cardiovascular complications & $265(28.3)$ & $147(23.3)$ & $118(38.7)$ \\
\hline Ischaemic heart disease & $123(13.1)$ & $79(12.5)$ & $44(14.4)$ \\
\hline Heart failure & $28(3.0)$ & $15(2.4)$ & $13(4.3)$ \\
\hline Peripheral arterial disease & $24(2.6)$ & $10(1.6)$ & $14(4.9)$ \\
\hline Stroke & $24(2.6)$ & $10(1.6)$ & $14(4.9)$ \\
\hline At least one macrovascular ${ }^{\text {a }}$ complication & $212(22.6)$ & $123(19.5)$ & $89(29.2)$ \\
\hline At least one microvascular ${ }^{b}$ complication & $239(25.5)$ & $112(17.7)$ & $127(41.6)$ \\
\hline \multicolumn{4}{|l|}{ Cardiovascular risk factors } \\
\hline Treated dyslipidaemia & $415(44.3)$ & $273(43.2)$ & $142(46.6)$ \\
\hline Treated hypertension & $734(78.3)$ & $470(74.4)$ & $264(86.6)$ \\
\hline BMI $\left(\mathrm{kg} / \mathrm{m}^{2}\right)$ & $29.2 \pm 5.1$ & $29.9 \pm 5.3$ & $27.6 \pm 4.4$ \\
\hline Normal $\left(\mathrm{BMI}<25 \mathrm{~kg} / \mathrm{m}^{2}\right)$ & $183(19.5)$ & $104(16.5)$ & $79(25.9)$ \\
\hline Overweight (BMI 25-30 kg/m²) & $402(42.9)$ & $249(39.4)$ & $153(50.2)$ \\
\hline Obese $\left(\mathrm{BMI} \geq 30 \mathrm{~kg} / \mathrm{m}^{2}\right)$ & $352(37.6)$ & $279(44.1)$ & $73(23.9)$ \\
\hline $\mathrm{HbA} 1 \mathrm{c}(\%)$ & $6.6 \pm 0.8$ & $6.5 \pm 0.8$ & $6.6 \pm 0.8$ \\
\hline Median (Q1 | Q3) & $6.4(6.1 \mid 6.9)$ & $6.4(6.0 \mid 6.9)$ & $6.5(6.1 \mid 7.0)$ \\
\hline$\geq 8.0 \%$ & $49(5.4)$ & $34(5.5)$ & $15(5.1)$ \\
\hline $7.0-8.0 \%$ & $172(18.9)$ & $106(17.2)$ & $66(22.4)$ \\
\hline $6.5-7.0 \%$ & $220(24.1)$ & $154(24.9)$ & $66(22.4)$ \\
\hline$<6.5 \%$ & $471(51.6)$ & $324(52.4)$ & $147(50.0)$ \\
\hline Missing data, $n$ & 25 & 14 & 11 \\
\hline \multicolumn{4}{|l|}{ Oral glucose-lowering treatment in monotherapy } \\
\hline Metformin & $564(60.2)$ & $428(67.7)$ & $136(44.6)$ \\
\hline Sulfonylurea & $274(29.2)$ & $147(23.3)$ & $127(41.6)$ \\
\hline Glinide & $47(5.0)$ & $19(3.0)$ & $28(9.2)$ \\
\hline$\alpha$-Glucosidase inhibitor & $27(2.9)$ & $17(2.7)$ & $10(3.3)$ \\
\hline DPP-4 inhibitor & $13(1.4)$ & $11(1.7)$ & $2(0.7)$ \\
\hline Thiazolidinedione & $12(1.3)$ & $10(1.6)$ & $2(0.7)$ \\
\hline
\end{tabular}

Data shown are $n(\%)$ of patients, mean \pm standard deviation, or median (quartile $1 \mid$ quartile 3 )

BMI: body mass index; DPP4-I: dipeptidyl peptidase-4; HbA1c: glycosylated haemoglobin; T2DM: type 2 diabetes mellitus.

a Ischaemic heart disease, peripheral arterial disease, stroke.

b Nephropathy, neuropathy, retinopathy.

and $7.0 \%$, and $24.3 \%$ had $\mathrm{HbAlc} \geq 7.0 \%$. These percentages were very similar in both younger and older patients (Table 2).

Of the 937 patients who had at least one follow-up visit, $916(97.9 \%)$ had at least two HbAlc values available. Of these, $390(42.6 \%)$ had poor glycaemic control (HbAlc $\geq 6.5 \%)$ (Supplementary Fig. 2), and 175 (19.1\%) had HbA1c $\geq 7.0 \%$ (Supplementary Fig. 3). The duration of poor glycaemic control was $13.4 \pm 9.0$ months, and $47 \%$ were uncontrolled for at least 12 months (corresponding values for $\mathrm{HbA} 1 \mathrm{c} \geq 7.0 \%$ were $10.8 \pm 7.4$ months, with $37 \%$ of patients uncontrolled for at least 12 months).

Of the 390 patients needing treatment intensification 164 $(42.1 \%)$ had their treatment intensified during follow-up (Supplementary Fig. 2); for a 7.0\% HbA1c target, 94/175 $(53.7 \%)$ were intensified (Supplementary Fig. 3). The probability of treatment intensification increased with poor glycaemic control. With an HbA1c target of $6.5 \%, 24 \%$ and $39 \%$ of the 390 patients received treatment intensification at 6 months and one year, respectively (Fig. 1). Corresponding values for the HbA1c target of $7.0 \%$ were $38 \%$ and $51 \%$, respectively (Supplementary Fig. 4).

The characteristics of the 226 uncontrolled patients $(\mathrm{HbA} 1 \mathrm{c} \geq 6.5 \%)$ without treatment intensification were similar to those of the 164 patients intensified, except for three characteristics: they were older $(69 \pm 11$ years vs. $66 \pm 12$ years, $P=0.02)$, with a lower first, uncontrolled HbA1c $(6.9 \% \pm 0.6$ vs. $7.3 \% \pm 0.8, P<0.0001)$, and they were less likely $(34.1 \%$ vs. $62.8 \%, P<0.0001)$ to have a second uncontrolled HbA1c value $\geq 7.0 \%$ (Table 3 ). Similarly, for a $7.0 \% \mathrm{HbA1c}$ target, the 81 patients without treatment intensification had a lower first and second uncontrolled $\mathrm{HbA1c}$ value $(7.3 \pm 0.6 \%$ vs. $7.6 \pm 0.8 \%$, $P<0.01)$ and $(7.5 \pm 0.5 \%$ vs. $7.9 \pm 0.8 \%, P<0.0001)$ respectively, than the 94 intensified patients. Other characteristics did not differ (Supplementary Table 1).

For the 390 uncontrolled patients (HbA1c $\geq 6.5 \%$ ), GPs most frequently reported their treatment objectives at inclusion as 


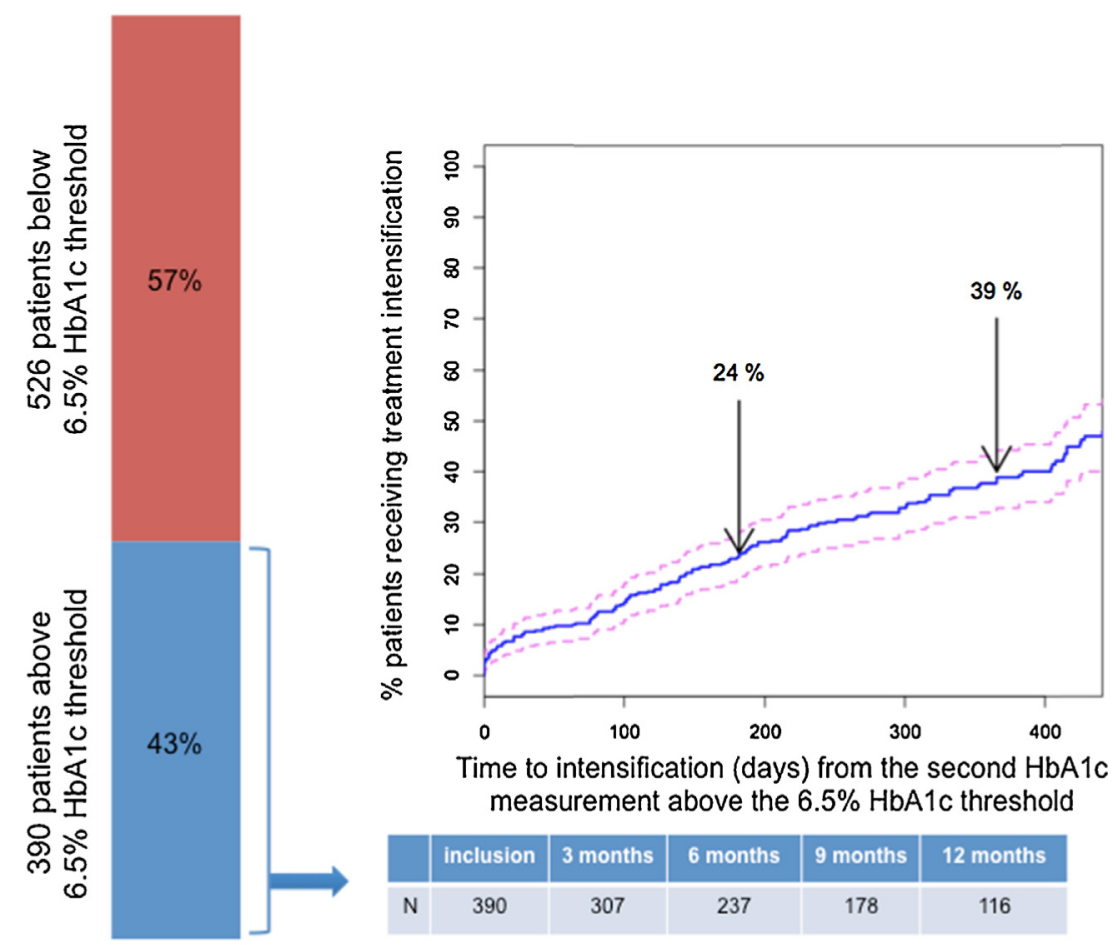

Fig. 1. Probability of treatment intensification according to the time since second haemoglobin A1c (HbA1c) over the 6.5\% threshold.

glycaemic control (46.2\%), encouragement of physical activity $(38.7 \%)$ and weight control or reduction/dietary measures (33.8\%). GP treatment objectives and demographic environments did not differ according to whether or not treatment was intensified (Table 3).

Uncontrolled patients received their first treatment intensification on average after 220 days $(\mathrm{HbA} 1 \mathrm{c} \geq 6.5 \%$ target) and 173 days (HbA1c $\geq 7.0 \%$ target). In $46.3 \%$ of cases, intensifications of glucose-lowering agents involved a transition from monotherapy to dual therapy (e.g. mainly from metformin to metformin + DPP-4), while $47.0 \%$ of cases involved increased doses of the current monotherapy. (Table 4 and Supplementary Table 2). Metformin dose was increased to $\geq 2.0 \mathrm{~g}$ for more than two in three patients for both $\mathrm{HbAlc}$ targets.

The average timing of $\mathrm{HbA} 1 \mathrm{c}$ testing following treatment intensification was 97 days (for $\mathrm{HbAlc}$ target $\geq 6.5 \%$ ) and 104 days ( $\mathrm{HbA} 1 \mathrm{c} \geq 7.0 \%$ ), but often too early to observe improvements: $18.1 \%$ were tested $<1$ month after intensification, $13.3 \%$ after 1-2 months, and $28.9 \%$ after 2-3 months.

Reasons given by GPs for non-intensification of T2DM treatment in uncontrolled patients $(\mathrm{HbAlc} \geq 6.5 \%)$ were that $\mathrm{HbA} 1 \mathrm{c}$ levels were considered adequate $(66.5 \%)$ and that implementation of dietary measures was preferred (14.4\%) (Table 5); for the HbAlc target $\geq 7.0 \%$ these percentages were $48.7 \%$ and $21.1 \%$, respectively (Supplementary Table 3 ). For the 143 patients with poor glycaemic control $(\mathrm{HbA} 1 \mathrm{c} \geq 6.5 \%)$ whose GPs considered their $\mathrm{HbA} 1 \mathrm{c}$ levels satisfactory, $69.2 \%$ had $\mathrm{HbA} 1 \mathrm{c} \geq 6.5 \%$ by less than $0.5 \%$, and only $2.1 \%$ had $\mathrm{HbA} 1 \mathrm{c}$ values $\geq 8.0 \%$; while $30.8 \%$ of these patients could have benefited from an intensification of treatment, only 3 patients $(2.1 \%)$ were poorly controlled. If poor glycaemic control was defined by $\mathrm{HbAlc} \geq 7.0 \%$, for the 37 patients for whom their GP considered their control adequate, $29.7 \%$ had an $\mathrm{HbA} 1 \mathrm{c}<7.5 \%$, and 3 patients $(8.1 \%)$ had an $\mathrm{HbA} 1 \mathrm{c} \geq 8.0 \%$.

Among elderly patients with poor glycaemic control whose treatment was not intensified, the most common reason for non-intensification was satisfactory HbA1c levels (Table 5 and Supplementary Table 3). In these patients, $61.4 \%$ had HbA1c levels exceeding $6.5 \%$ by less than $0.5 \%$, and $5.3 \%$ had $\mathrm{HbA} 1 \mathrm{c}$ values $\geq 8.0 \%$. Intensification in people aged over 75 years and uncontrolled $(\mathrm{HbA} 1 \mathrm{c}>6.5 \%)$ often involved a higher increase in metformin dose ( 2.55 or $3 \mathrm{~g} /$ day), than in those $<75$ years.

\subsection{Patient characteristics at the end of follow-up}

Among the 804 patients with a visit after 12 months of followup, $86.9 \%$ were on monotherapy, $10.9 \%$ were receiving dual therapy, $1.1 \%$ were receiving at least triple therapy, and $1.1 \%$ transitioned to insulin or GLP-1 analog treatments. During the 12 months of follow-up, 15 severe episodes of hypoglycaemia were observed in eight patients, seven of whom had received sulfonylurea or glinide in monotherapy (4 patients) or in combination with metformin ( 2 patients) or insulin (1 patient). The remaining patient was treated with metformin. Of these eight patients, four were uncontrolled $(\mathrm{HbAlc} \geq 6.5 \%)$ and three of them received treatment intensification during follow-up.

Patient weight fluctuated little over follow-up: $81.3 \pm 16.4 \mathrm{~kg}$ at inclusion, $81.1 \pm 16.6 \mathrm{~kg}$ after 12 months. Patients smoked less $(11.1 \%$ at inclusion, $8.8 \%$ at 12 months $[P=0.0094])$ and tended to exercise more frequently $(42.7 \%$ at inclusion, $46.5 \%$ at month $12[P=0.1315])$. Systolic and diastolic blood pressures were lower at 12 months $(P<0.001)$ in patients treated for hypertension at inclusion. 
Table 3

Characteristics at inclusion of patients with poor glycaemic control $(\mathrm{HbA} 1 \mathrm{c} \geq 6.5 \%)$, general practitioner (GP) treatment objectives and general practitioner characteristics, according to whether patients had their treatment intensified or not. The DIAttitude Study.

\begin{tabular}{|c|c|c|c|}
\hline Patient characteristics & $\begin{array}{l}\text { Non-intensified } \\
\text { patients } \\
(n=226)\end{array}$ & $\begin{array}{l}\text { Intensified } \\
\text { patients } \\
(n=164)\end{array}$ & $P$ \\
\hline Men & $140(61.9)$ & $93(56.7)$ & $0.3^{c}$ \\
\hline Age in 2010 (years) & $69 \pm 11$ & $66 \pm 12$ & $0.02^{d}$ \\
\hline $\mathrm{BMI}\left(\mathrm{kg} / \mathrm{m}^{2}\right)$ & & & $0.4^{\mathrm{c}}$ \\
\hline Normal $\left(\mathrm{BMI}<25 \mathrm{~kg} / \mathrm{m}^{2}\right)$ & $37(16.4)$ & $33(20.1)$ & \\
\hline $\begin{array}{l}\text { Overweight (BMI } \\
\left.25-30 \mathrm{~kg} / \mathrm{m}^{2}\right)\end{array}$ & $103(45.6)$ & $64(39.0)$ & \\
\hline Obese $\left(\mathrm{BMI} \geq 30 \mathrm{~kg} / \mathrm{m}^{2}\right)$ & $86(38.1)$ & 67 (40.9) & \\
\hline First uncontrolled $\mathrm{HbA} 1 \mathrm{c}(\%)$ & $6.9 \pm 0.6$ & $7.3 \pm 0.8$ & $<0.000$ \\
\hline $6.5-7.0 \%$ & $152(68.2)$ & $75(46.0)$ & \\
\hline$>7.0 \%$ & $71(31.8)$ & $88(54.0)$ & \\
\hline Missing data, $n$ & 3 & 1 & \\
\hline $\begin{array}{l}\text { Second uncontrolled } \mathrm{HbAlc} \\
(\%)\end{array}$ & $7.0 \pm 0.5$ & $7.5 \pm 0.8$ & $<0.000$ \\
\hline $6.5-7.0 \%$ & $149(65.9)$ & $61(37.2)$ & \\
\hline$>7.0 \%$ & $77(34.1)$ & $103(62.8)$ & \\
\hline Diabetes duration (years) & $8.0 \pm 7.2$ & $8.1 \pm 7.2$ & $0.7^{\mathrm{e}}$ \\
\hline Missing data, $n$ & 21 & 16 & \\
\hline $\begin{array}{l}\text { At least one macrovascular }{ }^{\mathrm{a}} \\
\text { complication }\end{array}$ & $54(23.9)$ & $33(20.1)$ & $0.4^{\mathrm{c}}$ \\
\hline $\begin{array}{l}\text { At least one microvascular } \\
\text { complication }\end{array}$ & $61(27.0)$ & $43(26.2)$ & $0.9^{c}$ \\
\hline \multicolumn{4}{|c|}{ Oral glucose-lowering treatment in monotherapy } \\
\hline Biguanide & $134(59.3)$ & $89(54.3)$ & $0.3^{c}$ \\
\hline Sulfonylurea & $71(31.4)$ & $59(36.0)$ & $0.3^{\mathrm{c}}$ \\
\hline Glinide & $15(6.6)$ & $7(4.3)$ & $0.3^{c}$ \\
\hline$\alpha$-Glucosidase inhibitor & $2(0.9)$ & $2(1.2)$ & $1.0^{\mathrm{f}}$ \\
\hline DPP4 inhibitor & $4(1.8)$ & $4(2.4)$ & $0.7^{\mathrm{f}}$ \\
\hline Thiazolidinedione & 0 & $3(1.8)$ & $0.07^{\mathrm{f}}$ \\
\hline \multicolumn{4}{|c|}{$\begin{array}{l}\text { GP treatment objectives at inclusion of patients in study (multiple } \\
\text { responses possible) }\end{array}$} \\
\hline $\begin{array}{l}\text { Bring } \mathrm{HbAlc} \text { levels to } \\
\text { recommended target }\end{array}$ & $103(45.6)$ & $77(47.0)$ & $0.8^{\mathrm{c}}$ \\
\hline $\begin{array}{l}\text { Bring } \mathrm{HbA} 1 \mathrm{c} \text { levels } \\
\text { to/maintain } \mathrm{HbA} 1 \mathrm{c} \text { levels at } \\
\text { recommended target }\end{array}$ & $76(33.6)$ & 49 (29.9) & $0.4^{\mathrm{c}}$ \\
\hline Control or reduce weight/diet & $75(33.2)$ & $57(34.8)$ & $0.7^{\mathrm{c}}$ \\
\hline Encourage physical activity & $90(39.8)$ & $61(37.2)$ & $0.6^{\mathrm{c}}$ \\
\hline Control risk factor(s) & $39(17.3)$ & $34(20.7)$ & $0.4^{\mathrm{c}}$ \\
\hline Avoid hypoglycaemia & $22(9.7)$ & $20(12.2)$ & $0.4^{\mathrm{c}}$ \\
\hline $\begin{array}{l}\text { Improve compliance and } \\
\text { awareness }\end{array}$ & $23(10.2)$ & $22(13.4)$ & $0.3^{\mathrm{c}}$ \\
\hline GP characteristics & 181 & 137 & \\
\hline Men & $146 / 181(80.7)$ & $101 / 136(74.3)$ & $0.2^{c}$ \\
\hline Age & $51 \pm 8$ & $50 \pm 8$ & $0.4^{\mathrm{d}}$ \\
\hline Type of practice & & & $0.5^{\mathrm{c}}$ \\
\hline Single GP & $15(53.6)$ & $13(44.8)$ & \\
\hline Group practice & $13(46.4)$ & $16(55.2)$ & \\
\hline Missing data, $n$ & 153 & 108 & \\
\hline
\end{tabular}

Data shown are $n(\%)$ of patients, mean \pm standard deviation.

BMI: body mass index; DPP4: dipeptidyl peptidase-4; GP: general practitioner;

HbA1c: glycosylated haemoglobin.

a Ischaemic heart disease, peripheral arterial disease, stroke.

b Nephropathy, neuropathy, retinopathy

${ }^{c} \mathrm{Chi}^{2}$ test.

d Student $t$-test.

e Wilcoxon test.

${ }^{\mathrm{f}}$ Fisher test
Table 4

Nature of oral glucose-lowering treatment intensifications in patients with poor glycaemic control $(\mathrm{HbAlc} \geq 6.5 \%)$. The DIAttitude study.

\begin{tabular}{|c|c|c|c|}
\hline $\begin{array}{l}\text { Nature of oral glucose-lowering } \\
\text { treatment }\end{array}$ & Total & $<75$ years & $\geq 75$ years \\
\hline $\begin{array}{l}\text { Intensified patients with poor } \\
\text { glycaemic control }\end{array}$ & 164 & $114(69.5)$ & $50(30.5)$ \\
\hline \multicolumn{3}{|l|}{ Add-on } & $18(36.0)$ \\
\hline $\mathrm{Big} \rightarrow \mathrm{Big}+\mathrm{DPP} 4-\mathrm{I}$ & $24(31.6)$ & $20(34.5)$ & $4(22.2)$ \\
\hline $\mathrm{Big} \rightarrow \mathrm{Big}+\mathrm{SU}$ & $9(11.8)$ & $9(15.5)$ & - \\
\hline $\mathrm{SU} \rightarrow \mathrm{SU}+\mathrm{Big}$ & $13(17.1)$ & $8(13.8)$ & $5(27.8)$ \\
\hline $\mathrm{SU} \rightarrow \mathrm{SU}+\mathrm{DPP} 4-\mathrm{I}$ & $11(14.5)$ & $9(15.5)$ & $2(11.1)$ \\
\hline \multicolumn{4}{|l|}{ Switch } \\
\hline $\mathrm{SU} \rightarrow \mathrm{Big}+\mathrm{DPP} 4-\mathrm{I}$ & $3(3.9)$ & $3(5.2)$ & - \\
\hline $\mathrm{Gli} \rightarrow \mathrm{Big}+\mathrm{SU}$ & $1(1.3)$ & - & $1(5.6)$ \\
\hline $\mathrm{TZD} \rightarrow \mathrm{Big}+\mathrm{DPP} 4-\mathrm{I}$ & $1(1.3)$ & $1(1.7)$ & - \\
\hline Other $^{\text {a }}$ & $14(18.4)$ & $8(13.8)$ & $6(33.3)$ \\
\hline Oral monotherapy dose increase & $77(47.0)$ & $49(43.0)$ & $28(56.0)$ \\
\hline Metformin titration & $46(59.7)$ & $32(65.3)$ & $14(50.0)$ \\
\hline SU titration & $25(32.5)$ & $14(28.6)$ & $11(39.3)$ \\
\hline Other drug titration & $6(9.2)$ & $3(6.1)$ & $3(10.7)$ \\
\hline $\begin{array}{l}\text { Oral monotherapy } \rightarrow \text { Oral } \\
\text { monotherapy dose } \\
\text { increase }+ \text { other oral therapy }\end{array}$ & $5(3.0)$ & $3(2.6)$ & $2(4.0)$ \\
\hline $\begin{array}{l}\text { Oral monotherapy } \rightarrow \\
\text { Insulin } \pm \text { oral therapy }\end{array}$ & $4(2.4)$ & $3(2.6)$ & $1(2.0)$ \\
\hline $\begin{array}{l}\text { Oral monotherapy } \rightarrow \text { GLP- } 1 \\
\text { receptor agonist } \pm \text { oral therapy }\end{array}$ & $1(0.6)$ & 0 & $1(2.0)$ \\
\hline $\begin{array}{l}\text { Oral monotherapy } \rightarrow \text { Oral } \\
\text { monotherapy dose } \\
\text { increase + other oral } \\
\text { therapy + GLP-1 receptor } \\
\text { agonist }\end{array}$ & $1(0.6)$ & $1(0.9)$ & 0 \\
\hline
\end{tabular}

Data shown are $n(\%)$ of patients.

Big: biguanide; SU: sulfonylurea; Gli: glinide; $\alpha$ Gluco-I: $\alpha$-Glucosidase inhibitor; DPP4-I: Dipeptidyl peptidase-4 inhibitor; TZD: thiazolidinedione; GLP-1: glucagon-like peptide-1; HbA1c: glycosylated haemoglobin.

${ }^{\text {a }} \mathrm{DPP} 4-\mathrm{I} \rightarrow \mathrm{DPP} 4-\mathrm{I}+\mathrm{Big} / \mathrm{SU} \rightarrow \mathrm{SU}+\alpha$ Gluco-I/Big $\rightarrow \mathrm{Big}+\alpha$ Gluco-

$\mathrm{I} / \mathrm{Gli} \rightarrow \mathrm{Gli}+(\mathrm{Big}$ or $\mathrm{DPP} 4-\mathrm{I}) / \mathrm{TZD} \rightarrow \mathrm{TZD}+(\mathrm{Big}$ or $\mathrm{SU}) / \mathrm{SU} \rightarrow \mathrm{SU}+\mathrm{Big}+$ DPP4-I/DPP4-I $\rightarrow$ DPP4-I + Big + SU.

Table 5

Reasons given by GPs for non-intensification of glucose-lowering treatment in T2DM patients with poor glycaemic control ( $\mathrm{HbA} 1 \mathrm{c} \geq 6.5 \%)$.

\begin{tabular}{|c|c|c|c|}
\hline $\begin{array}{l}\text { Reasons given by GPs for } \\
\text { non-intensification }\end{array}$ & $\begin{array}{l}\text { Total } \\
n=226\end{array}$ & $\begin{array}{l}<75 \text { years } \\
n=145\end{array}$ & $\begin{array}{l}\geq 75 \text { years } \\
n=81\end{array}$ \\
\hline No answer & 11 & 6 & 5 \\
\hline $\begin{array}{l}\mathrm{HbAlc} \text { levels were } \\
\text { adequate/satisfactory }\end{array}$ & $143(66.5)$ & $86(61.9)$ & $57(75.0)$ \\
\hline $\begin{array}{l}\text { Favour implementation of } \\
\text { dietary measures }\end{array}$ & $31(14.4)$ & $23(16.5)$ & $8(10.5)$ \\
\hline $\begin{array}{l}\text { Will make a decision at the next } \\
\text { visit }\end{array}$ & $15(7.0)$ & $13(9.4)$ & $2(2.6)$ \\
\hline $\begin{array}{l}\text { HbAlc levels have decreased } \\
\text { since the last visit }\end{array}$ & $8(3.7)$ & $6(4.3)$ & $2(2.6)$ \\
\hline $\begin{array}{l}\text { The patient consulted for } \\
\text { another purpose }\end{array}$ & $8(3.7)$ & $5(3.6)$ & $3(3.9)$ \\
\hline Other reasons & $10(4.7)$ & $6(4.3)$ & $4(5.3)$ \\
\hline
\end{tabular}

Data shown are $n(\%)$.

GPs: general practitioners; T2DM: type 2 diabetes mellitus; HbA1c: glycosylated haemoglobin. 


\section{Discussion}

The prospective DIAttitude study characterised the therapeutic management of orally-treated T2DM patients on monotherapy, and described treatment changes in a representative sample of French GPs and their patients: $43 \%$ of these patients required treatment intensification, and $42 \%$ received treatment intensification. These results are similar to those from the retrospective DIAttitude study with 17,000 orally-treated (not just monotherapy) T2DM patients [21]: 39\% required treatment intensification, and 59\% received treatment intensification within one year. In both studies, intensification was less likely in older patients, and more likely in those with higher $\mathrm{HbA} 1 \mathrm{c}$ values.

For the T2DM patients initially on monotherapy in the DIAttitude study, $52 \%$ were controlled ( $\mathrm{HbA} 1 \mathrm{c} \leq 6.5 \%)$, and only $5.4 \%$ had poor control (HbA1c $\geq 8 \%$ ). There was some clinical inertia or excessive treatment failure at inclusion in the study, with $5 \%$ having an $\mathrm{HbA} 1 \mathrm{c} \geq 8 \%$.

At inclusion, $60 \%$ of T2DM patients were treated by metformin, the first-line agent of choice in the DIAttitude study. Metformin is recommended for weight loss or maintenance and, unlike sulfonylureas, is not associated with hypoglycaemia [9]. In uncontrolled patients, $46.3 \%$ of treatment intensifications were transitions from monotherapy to bitherapy, and $47.0 \%$ were monotherapy dose increases. Metformin titration increased the dose to $>2.0 \mathrm{~g}$ in two in three cases, similar to doses reported by the UKPDS that were associated with a lower cardiovascular risk [23]. For patients on one tablet/day, an increase in metformin dose is recommended, but bitherapy is a better for those on two tablets [24]. In older patients, we more frequently observed monotherapy dose increases to maintain compliance and avoid polypharmacy (Table 4); however, high metformin doses may not be desirable due to digestive intolerance and the frequent coexistence of renal failure.

Following recommendations [9], stringent $\mathrm{HbAlc}$ glycaemic targets can be implemented in many patients on monotherapy, as they are easy to treat. Few complications (e.g. severe hypoglycaemia episodes) were observed in the DIAttitude study, with relatively low $\mathrm{HbA} 1 \mathrm{c}$ levels, and stable weight and hypertension profiles.

At inclusion, the most frequently cited GP treatment objective for uncontrolled T2DM patients receiving oral monotherapy was glycaemic control (46.2\%) (Table 1). The probability of treatment intensification increased with the degree of poor glycaemic control. The main reason for non-intensification of treatment, regardless of patient age, was that the $\mathrm{HbA} 1 \mathrm{c}$ level was considered satisfactory, and this reason was more frequently cited for patients $\geq 75$ years. It is important to note that for those patients whose treatment was not intensified, two thirds had HbA1c levels exceeding recommended targets by less than $0.5 \%$, which cannot be considered 'poor' glycaemic control.

Diabetes is treated differently in elderly patients, depending on disease duration and control. GPs implemented less stringent HbA1c glycaemic control objectives in patients $\geq 75$ years, as they less frequently had their treatment intensified, in accordance with treatment recommendations $[9,10]$. It should be noted that a UK study reported that GPs were reluctant to initiate treatment in older patients because of potential hypoglycaemia, and only initiated treatment when $\mathrm{HbA} 1 \mathrm{c}$ levels exceeded recommended values [25]. Other studies investigating clinical inertia have also reported treatment intensification to be associated with younger age and higher baseline HbAlc values [12,26-28]. These studies reported longer delays in treatment intensification than in the DIAttitude study. Comorbidity and hypoglycaemia were not associated with non-intensification.

The lack of a significant reduction in cardiovascular events with intensive glycaemic control observed in several randomised controlled trials in T2DM patients has started to influence clinical decisions [29-34], but should not lead clinicians to abandon the general $\mathrm{HbA} 1 \mathrm{c}<7.0 \%$ target. While cardiovascular risk is a major concern in T2DM, the benefit of glycaemic control on microvascular complications should not be disregarded. Glycaemic control remains a well-established key determinant in the prevention of microangiopathy in T2DM. Adjustment of treatment objectives according to patient and disease factors is paramount in T2DM management, as not every patient benefits from intensive glucose management [9]. For patients with a shorter diabetes duration, longer life expectancy and no significant cardiovascular disease, HbAlc targets below $7.0 \%$ or even below $6.5 \%$ may be appropriate, if this can be achieved without adverse effects (e.g. hypoglycaemia).

The results presented have to be considered against potential limitations inherent to observational studies. Potential biases related to GP and patient selection were not relevant, because the study software prevented GPs from selecting specific patients. No evidence of reporting bias was observed, as management of T2DM patients was comparable to management by all GPs in the CSD panel. Additionally, because the majority of T2DM patients in France are treated by GPs rather than by specialists [20], attrition bias was considered minimal. Unfortunately we have no information on the target HbA1c of GPs for individual patients. Further, the $\mathrm{HbAlc}$ testing recorded would not only be routine, but would also include more frequent testing for patients with higher or unstable HbAlc, making it likely that more 'uncontrolled' values would be observed.

It is difficult to compare the level of clinical inertia in our study with that of other studies, as the protocols differ according to the definition of clinical inertia (the definition of 'control', the target value for $\mathrm{HbA} 1 \mathrm{c}$ ) and the follow-up period.

However, there is a pan-European study of people with type 2 diabetes where a sulfonylurea or a thiazolidinedione was added to metformin, between January 2001 and January 2006 [13]. After 2.4 years of treatment, the percentage of people with $\mathrm{HbAlc} \geq 6.5 \%$, who could be considered to be concerned by clinical inertia was $70 \%$ in France, a little lower than that in other countries, but much lower than in the United Kingdom or Norway ( $82 \%$ and $84 \%$ respectively). These results pertain to a specific group of people initially on metformin monotherapy with their treatment intensified by one of two drugs, with no account taken of those intensified by an increased dose of metformin. The study period is almost 10 years earlier than our 
study, with a longer follow-up, the definition of 'clinical inertia' is different and the guidelines differ.

A recently published study from the United Kingdom Clinical Practice Research Datalink database included people starting an oral glucose-lowering regimen between January 2004 and December 2006 [35], who were followed until April 2011-up to 7 years. Of those on monotherapy, and with $\mathrm{HbA} 1 \mathrm{c} \geq 7.0 \%$ at baseline, $72 \%$ had their treatment intensified, thus clinical inertia would concern fewer than $28 \%$ in this population. If we defined clinical inertia for our one-year study as non-intensification of treatment for a baseline $\mathrm{HbA} 1 \mathrm{c} \geq 7.0 \%$, then clinical inertia would concern $46 \%$ of our population.

\section{Conclusion}

Our results confirm persistent clinical inertia in the management of patients with T2DM, which could be explained by the individualisation of treatment goals for only some patients. Treatment objectives must be individualised, and guidelines require careful interpretation when translated into clinical practice. The reasons for non-intensification in our study were mainly the patient's age and an HbAlc level close to the $6.5 \%$ target.

\section{Contributor statements}

B.B. E.A., I.C. and S.H. contributed to the study design and conduct, data analysis and the writing of the article.

J.F.B., B.V., A.A. and C.A. contributed to the study design and conduct, data analysis and the revision of the manuscript.

\section{Disclosure of interest}

B.B. is on advisory committees for AstraZeneca, Boehringer Ingelheim, Bristol-Myers Squibb, Lilly, Novo and Sanofi.

J.-F.B. has received consulting fees and honoraria from AstraZeneca/Bristol-Myers Squibb, Boehringer Ingelheim, GSK, Lilly, Merck Serano, Merck Sharp \& Dohme-Chibret, Novartis, Novo Nordisk, Roche, Sanofi, Servier and Takeda.

B.V. has received consulting fees and honoraria for lectures from AstraZeneca/Bristol-Myers Squibb, Bayer Pharma, Boehringer Ingelheim, Lilly, Merck Sharp \& DohmeChibret, Novartis Pharma, Novo Nordisk, Sanofi, Servier and Takeda.

A.A. has received consulting fees and honoraria for lectures from AstraZeneca/Bristol-Myers Squibb, Lilly, Novo Nordisk, Sanofi, Merck Sharp \& Dohme-Chibret.

C.A. has received consulting fees from Novartis, Boehringer Ingelheim and AstraZeneca.

E.A. is a Bristol-Myers Squibb employee.

I.C. is an Aixial-Pharma employee.

S.H. is on advisory committees, and is a laboratory investigator for AstraZeneca, Boehringer Ingelheim, Bristol-Myers Squibb, Lilly, MSD, Novartis, NovoNordisk, Roche Diagnostics, Sanofi and Takeda.
B.B., J.-F.B., B.V., A.A., C.A. and S.H. have all received honoraria for participating in the Scientific Board for this study.

\section{Acknowledgements}

The authors thank Dr Vanessa Gray-Schopfer, OmniScience SA and Dr Julian Martins, Springer Healthcare who provided medical writing services.

The authors thank Marie-Agnès Geoffroy (Docs International) for her contribution to the study management.

The authors were fully responsible for the content and editorial decisions of this manuscript.

Funding: this study was conducted in partnership with the French-Speaking Diabetes Society (SFD) and was funded by Bristol-Myers Squibb and AstraZeneca.

\section{References}

[1] Danaei G, Finucane MM, Lu Y, Singh GM, Cowan MJ, Paciorek CJ, et al. National, regional, and global trends in fasting plasma glucose and diabetes prevalence since 1980: systematic analysis of health examination surveys and epidemiological studies with 370 country-years and 2.7 million participants. Lancet 2011;378:31-40.

[2] Whiting DR, Guariguata L, Weil C, Shaw J. IDF diabetes atlas: global estimates of the prevalence of diabetes for 2011 and 2030. Diabetes Res Clin Pract 2011;94:311-21.

[3] Holman RR, Paul SK, Bethel MA, Matthews DR, Neil HA. 10-year follow-up of intensive glucose control in type 2 diabetes. $\mathrm{N}$ Engl $\mathbf{J}$ Med 2008;359:1577-89

[4] Stratton IM, Adler AI, Neil HA, Matthews DR, Manley SE, Cull CA, et al. Association of glycaemia with macrovascular and microvascular complications of type 2 diabetes (UKPDS 35): prospective observational study. BMJ 2000;321:405-12.

[5] Selvin E, Marinopoulos S, Berkenblit G, Rami T, Brancati FL, Powe NR, et al. Meta-analysis: glycosylated hemoglobin and cardiovascular disease in diabetes mellitus. Ann Intern Med 2004;141:421-31.

[6] Li R, Zhang P, Barker LE, Chowdhury FM, Zhang X. Cost-effectiveness of interventions to prevent and control diabetes mellitus: a systematic review. Diabetes Care 2010;33:1872-94.

[7] Nichols GA, Alexander CM, Girman CJ, Kamal-Bahl SJ, Brown JB. Treatment escalation and rise in $\mathrm{HbA} 1 \mathrm{c}$ following successful initial metformin therapy. Diabetes Care 2006;29:504-9.

[8] Turner RC, Cull CA, Frighi V, Holman RR. Glycemic control with diet, sulfonylurea, metformin, or insulin in patients with type 2 diabetes mellitus: progressive requirement for multiple therapies (UKPDS 49). UK Prospective Diabetes Study (UKPDS) Group. JAMA 1999;281:2005-12.

[9] Inzucchi SE, Bergenstal RM, Buse JB, Diamant M, Ferrannini E, Nauck M, et al. Management of hyperglycemia in type 2 diabetes: a patient-centered approach: position statement of the American Diabetes Association (ADA) and the European Association for the Study of Diabetes (EASD). Diabetes Care 2012;35:1364-79.

[10] AFSSAPS-HAS. Recommandation professionnelle. Traitement médicamenteux du diabète de type 2 (Actualisation); 2006 [Available from http:// www.omedit-hautenormandie.fr/Files/108_recommandations_bon_usage_ diabete_type_2.pdf. Accessed 20 September 2015].

[11] HAS, ANSM. Recommandation de bonne pratique. Stratégie médicamenteuse du contrôle glycémique du diabète de type 2; 2013 
[Available from http://www.has-sante.fr/portail/upload/docs/application/ pdf/2013-02/10irp04_reco_diabete_type_2.pdf. Accessed 20 September 2015].

[12] McEwen LN, Bilik D, Johnson SL, Halter JB, Karter AJ, Mangione CM, et al. Predictors and impact of intensification of antihyperglycemic therapy in type 2 diabetes: translating research into action for diabetes (TRIAD). Diabetes Care 2009:32:971-6.

[13] Alvarez Guisasola F, Mavros P, Nocea G, Alemao E, Alexander CM, Yin D. Glycaemic control among patients with type 2 diabetes mellitus in seven European countries: findings from the Real-Life Effectiveness and Care Patterns of Diabetes Management (RECAP-DM) study. Diabetes Obes Metab 2008;10:8-15.

[14] Phillips LS, Branch WT, Cook CB, Doyle JP, El-Kebbi IM, Gallina DL, et al. Clinical inertia. Ann Intern Med 2001;135:825-34.

[15] Phillips LS, Twombly JG. It's time to overcome clinical inertia. Ann Intern Med 2008;148:783-5.

[16] Detournay B, Cros S, Charbonnel B, Grimaldi A, Liard F, Cogneau J, et al. Managing type 2 diabetes in France: the ECODIA survey. Diabetes Metab 2000;26:363-9.

[17] Romon I, Fosse S, Weill A, et al. Prévalence des complications macrovasculaires et niveau de risque vasculaire des diabétiques en France, étude Entred 2001. Bull Epidemiol Hebd (BEH) 2005;12-13:46-8 [Available from http://opac.invs.sante.fr/doc_num.php?explnum_id=5601. Accessed 20 September 2015].

[18] Entred 2007-2010. Résultats épidémiologiques principaux d'Entredmétropole; 2014 [Available from http://www.invs.sante.fr/fr/Dossiersthematiques/Maladies-chroniques-et-traumatismes/Diabete/EtudesEntred/Etude-Entred-2007-2010/Resultats-epidemiologiques-principauxd-Entred-metropole. Accessed 20 September 2015].

[19] Fagot-Campagna A, Fosse S, Roudier C, Comité scientifique d'Entred, et al. Caractéristiques, risque vasculaire et complications chez les personnes diabétiques en France métropolitaine: d'importantes évolutions entre Entred 2001 et Entred 2007. Bull Epidemiol Hebdo (BEH) 2009;42-43:450-5 [Available from http://www.invs.sante. fr/beh/2009/42_43/beh_42_43_2009.pdf. Accessed 20 September 2015].

[20] Robert J, Roudier C, Poutignat N, pour le comité scientifique d'Entred 2007-2010, et al. Prise en charge des personnes diabétiques de type 2 en France en 2007 et tendances par rapport à 2001. Bull Epidemiol Hebdo (BEH) 2009;42-43:455-60 [Available from http://www.invs.sante.fr/ beh/2009/42_43/beh_42_43_2009.pdf. Accessed 20 September].

[21] Balkau B, Bouee S, Avignon A, Vergès B, Chartier I, Amelineau E, et al. Type 2 diabetes treatment intensification in general practice in France in 2008-2009: the DIAttitude Study. Diabetes Metab 2012;38:S29-35.

[22] Halimi S, Balkau B, Attali C, Detournay B, Amelineau E, Blickle JF. Therapeutic management of orally-treated type 2 diabetic patients, by French general practitioners in 2010: the DIAttitude Study. Diabetes Metab 2012;38:S36-46.
[23] UK Prospective Diabetes Study (UKPDS) Group. Effect of intensive bloodglucose control with metformin on complications in overweight patients with type 2 diabetes (UKPDS 34). Lancet 1998;352:854-65.

[24] Scarpello JHB. Optimal dosing strategies for maximising the clinical response to metformin in type 2 diabetes. Br $\mathbf{J}$ Diabetes Vasc Dis 2001;1:28-36

[25] Zhang Q, Marrett E, Jameson K, Meiler S, Davies MJ, Radican L, et al. Reasons given by general practitioners for non-treatment decisions in younger and older patients with newly diagnosed type 2 diabetes mellitus in the United Kingdom: a survey study. BMC Endocr Disord 2011;11:17.

[26] Fu AZ, Qiu Y, Davies MJ, Radican L, Engel SS. Treatment intensification in patients with type 2 diabetes who failed metformin monotherapy. Diabetes Obes Metab 2011;13:765-9.

[27] Raebel MA, Ellis JL, Schroeder EB, Xu S, O'Connor PJ, Segal JB, et al. Intensification of antihyperglycemic therapy among patients with incident diabetes: a Surveillance Prevention and Management of Diabetes Mellitus (SUPREME-DM) study. Pharmacoepidemiol Drug Saf 2014;23: 699-710.

[28] Mata-Cases M, Benito-Badorrey B, Roura-Olmeda P, Franch-Nadal J, Pepió-Vilaubí JM, Saez M, et al. GEDAPS (Primary Care Group for the study of Diabetes) of the Catalonian Society of Family and Community Medicine. Clinical inertia in the treatment of hyperglycemia in type 2 diabetes patients in primary care. Curr Med Res Opin 2013;29:1495-502.

[29] Duckworth W, Abraira C, Moritz T, Reda D, Emanuele N, Reaven PD, et al. Glucose control and vascular complications in veterans with type 2 diabetes. N Engl J Med 2009;360:129-39.

[30] ADVANCE Collaborative Group, Patel A, MacMahon S, Chalmers J, Neal $\mathrm{B}$, Billot L, et al. Intensive blood-glucose control and vascular outcomes in patients with type 2 diabetes. N Engl J Med 2008;358:2560-72.

[31] Action to Control Cardiovascular Risk in Diabetes Study Group, Gerstein HC, Miller ME, Byington RP, Goff Jr DC, Bigger JT, et al. Effects of intensive glucose-lowering in type 2 diabetes. N Engl J Med 2008;358:2545-59.

[32] Boussageon R, Bejan-Angoulvant T, Saadatian-Elahi M, Lafont S, Bergeonneau C, Kassaï B, et al. Effect of intensive glucose-lowering treatment on all cause mortality, cardiovascular death, and microvascular events in type 2 diabetes: meta-analysis of randomised controlled trials. BMJ 2011;343:d4169.

[33] Hemmingsen B, Lund SS, Gluud C, Vaag A, Almdal T, Hemmingsen C, et al. Intensive glycaemic control for patients with type 2 diabetes: systematic review with meta-analysis and trial sequential analysis of randomised clinical trials. BMJ 2011;343:d6898.

[34] Preiss D, Ray KK. Intensive glucose-lowering treatment in type 2 diabetes. BMJ 2011:343:d4243.

[35] Khunti K, Wolden ML, Thorsted BL, Andersen M, Davies MJ. Clinical inertia in people with type 2 diabetes: a retrospective cohort study of more than 80,000 people. Diabetes Care 2013:36:3411-7. 